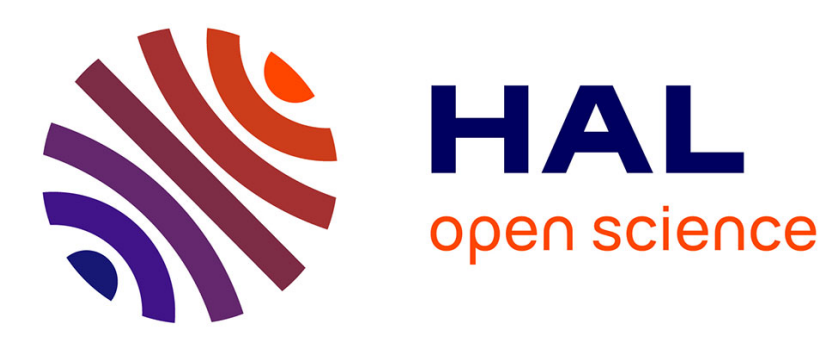

\title{
The origin of the causative prefix in Rgyalrong languages and its implication for proto-Sino-Tibetan reconstruction
}

\author{
Guillaume Jacques
}

\section{- To cite this version:}

Guillaume Jacques. The origin of the causative prefix in Rgyalrong languages and its implication for proto-Sino-Tibetan reconstruction. Folia Linguistica, 2015, Historica, 36: (36), pp.165-198. halshs01244869

\section{HAL Id: halshs-01244869 \\ https://shs.hal.science/halshs-01244869}

Submitted on 16 Dec 2015

HAL is a multi-disciplinary open access archive for the deposit and dissemination of scientific research documents, whether they are published or not. The documents may come from teaching and research institutions in France or abroad, or from public or private research centers.
L'archive ouverte pluridisciplinaire HAL, est destinée au dépôt et à la diffusion de documents scientifiques de niveau recherche, publiés ou non, émanant des établissements d'enseignement et de recherche français ou étrangers, des laboratoires publics ou privés. 


\title{
The origin of the causative prefix in Rgyalrong languages and its implication for proto-Sino-Tibetan reconstruction ${ }^{*}$
}

\author{
Guillaume Jacques
}

December 16, 2015

\begin{abstract}
This paper presents the first detailed description of the two causative derivations in Japhug Rgyalrong based on a corpus of spontaneous speech, and proposes two new pathways of grammaticalization: causative from denominal derivation and abilitative from causative.

Then, it evaluates the implication of these grammaticalization hypotheses for the reconstruction of Sino-Tibetan morphology as a whole.

Keywords: Causative, Denominal verbs, Japhug, Rgyalrongic, Grammaticalization, Abilitative, Sino-Tibetan
\end{abstract}

\section{Introduction}

Ever since Conrady (1896)'s seminal work on comparative Sino-Tibetan, the hypothesis that a causative ${ }^{*} \mathrm{~s}$ - prefix can be reconstructed for the common ancestor of Chinese, Tibetan and all related languages has been widely accepted and can be said to be the only fact about proto-Sino-Tibetan morphosyntax that is completely uncontroversial (Wolfenden 1929, Benedict 1972, Matisoff 2003, LaPolla 2003). Yet, despite this consensus, the history of the causative prefix in the ST family is by no means trivial.

In many Sino-Tibetan languages, including Old Chinese, the language with oldest attestations, the causative prefix can only be indirectly detected

\footnotetext{
${ }^{*}$ The glosses follow the Leipzig glossing rules. Other abbreviations used here are: AUTO autobenefactive-spontaneous, ANTICAUS anticausative, ANTIPASS antipassive, APPL applicative, DEM demonstrative, DIST distal, EMPH emphatic, FACT factual, GENR generic, IFR inferential, INDEF indefinite, INV inverse, LNK linker, PFV perfective, POSS possessor, SENS sensory. I would like to thank Nathan W. Hill, Laurent Sagart and three anonymous reviewers for valuable comments and suggestions on a previous version of this article. The examples are taken from a corpus that is progressively being made available on the Pangloss archive (Michailovsky et al. 2014). This research was funded by the HimalCo project (ANR-12-CORP-0006) and is related to the research strand LR-4.11 "Automatic Paradigm Generation and Language Description" of the Labex EFL (funded by the ANR/CGI).
} 
through internal reconstruction. In phonologically more conservative languages such as Old Tibetan, the causative prefix is directly attested, but restricted to a limited number of examples and completely lexicalized. Rgyalrong is one of the few language groups in Sino-Tibetan where the causative is still productive (ie can be applied to recent loanwords). ${ }^{1}$ Thus, a detailed description of the morphosyntax of the causative in Rgyalrong languages is necessary before any further comparative research.

In this paper, we first provide an overview of the morphology and morphosyntax of the causative prefixes su- and $\gamma^{\gamma}$-in Japhug Rgyalrong, one of the Rgyalrong languages, and discuss the historical relationship of the causative prefix with homophonous prefixes, in particular the abilitative and the denominal instrumental sur-. Then, we show on the basis of comparative evidence that the likeliest explanation for the homophony between the causative and the denominal prefixes in Rgyalrong languages is due to the fact that the former was grammaticalized from the latter. Finally, we present comparative evidence from Chinese, Tibetan and Kiranti showing that the lexicalized remnants of the causative and denominal prefixes in these languages are compatible with the grammaticalization hypothesis presented in section 3 .

\section{The causative in Rgyalrongic languages}

Rgyalrongic languages are particularly crucial for understanding the morphosyntax of the causative in Sino-Tibetan as a whole, as they constitute the only subgroup of the family where the causative is still fully productive and can be applied to recent loanwords, at least in the four core Rgyalrong languages Situ, Japhug, Tshobdun and Zbu. It is thus of considerable importance, before any diachronic research, to describe the synchronic system of these conservative languages in detail, and then evaluate how much of this system has been preserved elsewhere. Since previous description of Rgyalrong languages only briefly discuss the morphosyntax of the causative constructions (see Sun 2006, Jacques 2008), it is necessary at this stage to provide the first in depth description of the use of the causative prefixes in a Rgyalrong language.

In this paper, we focus on the Japhug language, but similar causative prefixes are found in Tshobdun (Sun 2006, 2014) and in Khroskyabs (Lai 2013, 2014), and the facts described for Japhug are valid for Rgyalrongic as a whole.

This section comprises four subsections. First, we describe the morphology and uses of the causative prefixes sur-and $\gamma^{\gamma}$-respectively, as well as

\footnotetext{
${ }^{1}$ There may be other languages in which this prefix is productive, such as Jinghpo or Dulong (see Dai 1990: 71-8 and Sūn 1982: 101-2), but additional data is necessary, especially concerning the treatment of loanwords.
} 
the semantic distinctions between the two. Then, we treat the homophonous abilitative and denominal su- and discuss their potential historical relationships with the causative.

\subsection{The causative prefix su-}

Unlike most Sino-Tibetan languages, Rgyalrong languages have a complex templatic prefixal morphology (Jacques 2013b, Sun 2014) and numerous valency increasing and decreasing prefixes, including reflexive (Jacques 2010), passive, anticausative (Jacques 2012c), applicative (Jacques 2013a), antipassive (Jacques 2014a) as well as nominal incorporation (Jacques 2012d).

Of all the derivational verbal morphological processes in Japhug, the causative $s u-/ z-/$ sur $^{-}$is the most commonly used, the most productive and the morphophonologically most complex affixal element, a fact that betrays its antiquity in comparison with other affixes, most of which can be shown to be recent developments (see in particular Jacques 2014a).

\subsubsection{Morphophonology}

Although not as complex as the causative in Stodsde (Sun 2007) or in Khroskyabs (Lai 2014), the Japhug causative su- prefix presents considerable allomorphy, and numerous irregular forms. It has four regular allomorphs sur-, sur $\gamma^{-}, z^{-}$and $s \gamma$-depending on the following element.

The $z$-allomorph appears before all derivational prefixes (or unanalysable prefixal elements synchronically belonging to the verb root) with sonorant initial (beginning in $r-, n-, \gamma^{-}$or $m$-). Table 1 illustrates some examples of this allomorph.

Table 1: Examples of the $z$-allomorph of the causative prefix

\begin{tabular}{lllll}
\hline nature of the prefix & base & \multicolumn{3}{c}{ derived } \\
\hline non-analysable & mummu & move & $z$-munmu & cause to move \\
& nuna & rest & z-numa & stop \\
denominal & nrma & work & $z$-nrma & cause to work \\
antipassive $r \boldsymbol{r}$ - & rrrrt & write & $z$-rrrrt & cause to write \\
\hline
\end{tabular}

The distribution of the sur- and sury-allomorphs depends on both phonology and morphology. The latter allomorph occurs when the base verb is intransitive, has no prefixal element, has no initial cluster and no velar or uvular initial consonant, and the former appears in all other cases.

A fourth predictable allomorph of su- appears with verbs whose stem begins in $a-$, where sur- and the $a$ - passive prefix or intransitive thematic element merge as $\boldsymbol{s} \boldsymbol{\gamma}$-, as in Table 3. 
Table 2: The sur- and sury-allomorphs of the causative prefix

\begin{tabular}{lllll}
\hline transitivity & base & \multicolumn{3}{c}{ derived } \\
\hline intr. & ce & go & sur- e & send \\
tr. & cum & brood & sur- cum & cause to brood \\
intr. & ndzur & stand & sury-ndzur & cause to stand up \\
tr. & ndza & eat & sul-ndza & cause to eat \\
intr. & tso & understand & sur-tso & cause to understand \\
tr. & tsum & take away & sur-tsum & cause to take away, send \\
\hline
\end{tabular}

Table 3: The $\boldsymbol{s} \boldsymbol{\gamma}$ - allomorph of the causative prefix

\begin{tabular}{llll}
\hline base & & derived & \\
\hline ambrrqrt & be different & srmbrrqrt & distinguish \\
andujja & gather & srnduja & cause to gather \\
amprm & be homogeneous & srmprm & homogenize \\
\hline
\end{tabular}

The causative has four additional irregular allomorphs: $s$ - and $j$. All known examples are presented in Table 4.

Some of the verbs in Table 4, such as $t s^{h}$ "to drink", $p^{h} \gamma_{0}$ "to flee", lury "to get free" and rga "to be glad, to like", can appear with the regular causative sur-. In the first cases the meaning of the derived verbs are slightly different:

1. sur-tshi means "make s.o. drink" rather than "give s.t. to drink to s.o."

2. su-p p $^{h}$ "make someone escape" instead of "take away"

3. sur-lury "cause to get free" instead of "drop"

We observe that the regular causatives also have a regular semantic derivation from the basic verbs. The irregular causatives of these verbs can be used with the additional regular causative (sur-clury "cause to drop"). We can infer from these two facts that some of the irregular causatives (not including those in $6 u-$-) are no longer synchronically causatives or the original verb, as their meaning has begun to evolve independently.

The presence of a Tibetan loanword rga "to be glad, to like" (from Tibetan dga) in this list shows that these allomorphs were still productive relatively recently.

The original distribution of the allomorphs in alveolo-palatals cur-, cury-, $\epsilon^{-}$and $\xi^{-}$is unclear. They are only marginally restricted by the place of articulation of the initial consonant (they occur with labial, dental, velar and uvular - all except alveolo-palatal and palatal consonants), and occur with both simple initials and complex clusters. 
Table 4: The irregular allomorphs of the causative prefix

\begin{tabular}{|c|c|c|c|}
\hline base & & derived & \\
\hline fka & be full (after eating) & cuI-fka & cause to be full \\
\hline$f k a \beta$ & cover & GuI-fkaß & cover with something \\
\hline mbуom & be in a hurry & 6ü-mbyom & cause to be in a hurry \\
\hline mnrm & have a smell & GuI-mnrm & cause to have a smell \\
\hline$m \eta r m$ & hurt (of a body part) & GuI-mワrm & hurt (somebody) \\
\hline$n t a \beta$ & be stable & cu-nta $\beta$ & put \\
\hline ngo & sick & Gu-ngo & cause to become sick \\
\hline nпo & lose & ६щu-пџо & win \\
\hline NqOB & be hung & GUI-NQOB & hang \\
\hline rgo & borrow & 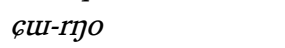 & lend \\
\hline (tur-mbruI) நgu & be / become angry & (tuu-mbru) $6 u-\eta g g u$ & anger someone \\
\hline rпgut & lie down & Gu-rngu & $\begin{array}{l}\text { cause to lie down, } \\
\text { ferment (alcohol) }\end{array}$ \\
\hline rga & be glad & cuI-rga & please somebody \\
\hline$m u$ & be afraid & ситу-ти & frighten \\
\hline$p^{h}$ YO & flee & $6 p^{h} Y O$ & take away \\
\hline luty & get loose, get free & clury & drop \\
\hline NqOB & be hung & ZNGOB & hang on a hook \\
\hline gga & wear & żga & help someone to wear \\
\hline mbri & cry & zmbri & play (an instrument) \\
\hline$t s^{h} i$ & drink & $j t s^{h} i$ & give to drink \\
\hline qanu & dark & sqanu & put in darkness \\
\hline
\end{tabular}

6ur-, like sur-, probably occurred with intransitive verbs without initial cluster, possibly with labial initials. We will see that a similar $-\gamma$-intrusive element appears with the applicative and the tropative prefixes.

$s$ - seems to occur with polysyllabic verb stems whose first element begins with a voiceless stop.

It is interesting to note that $к q о в$ has two distinct irregular causatives with different meanings; zNGOB is not a causative any more from a synchronic point of view, since it can appear with a causative prefix sur- (meaning "hang with something", see 2.1.2). The causative $j t s^{h}$ of $t s^{h} i$ is only found in the Kamnyu dialect of Japhug. In most Japhug dialects, where the verb "to drink" is $t^{h} i$, its irregular causative is $6 t^{h} i$. The Kamnyu form results from a dissimilation ${ }^{*}{ }_{6} t^{h} i>{ }^{*}{ }_{\epsilon} s^{h}{ }_{i}>j t s^{h}$.

A few causative verbs not derived from intransitives in $a$ - have the allomorph $s \boldsymbol{r}$, in particular srpe "do well" (from pe "be good") and srrmi "give a name" (from rmi "be named"). The latter could however perhaps be analysed as a denominal verb from tr-rmi "name".

The allomorphy of the causative prefix in Rgyalrongic languages raises a more general methodological question: should we assume that Rgyalrongic 
languages are innovative and that the observed allomorphy is due to relatively recent sound changes, or should this allomorphy be reconstructed back to proto-Rgyalrongic or even earlier? Given the present status of protoRgyalrongic reconstruction, a discussion of this issue has to be deferred to future research but we should keep in mind, when analyzing data from languages where no allomorphy is detectable that the absence of allomorphy may be due to levelling, rather than absence of innovative sound change.

\subsubsection{Syntactic constructions}

The causative prefix sur- is the most common morphosyntactic device to express causation in Japhug, though not the only one. ${ }^{2}$

When the causative is applied to an intransitive verb, the $\mathrm{S}$ becomes the $\mathrm{O}$ of the derived verb (Dixon 2000: 45) . The A of the derived verb corresponds to the causer or the stimulus of the causation. The following example of the verb sul-rsdrt [sasdrt] "to cause to slip", causative of aвdrt "to slip", illustrates this principle:

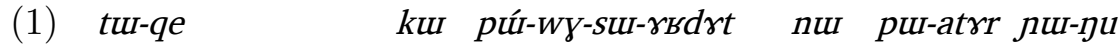

INDEF.POSS-dung ERG PFV-INV-CAUS-slip DEM PFV-fall IPF-be

The dung caused him to slip and he fell down. (The Demon, 51)

With transitive verbs, a different situation is observed. The causative derivation adds an argument, the causer, which becomes the A of the causative verb. Since Japhug verbs cannot encode more than two arguments in their morphology, one of the arguments of the base verb must be demoted to leave place for the causer. Four types of derivations are observed.

First, the causee (the $\mathrm{A}$ of the original verb) becomes the $\mathrm{O}$ of the derived verb, while the original $\mathrm{O}$ is demoted. Most causatives are formed this way: ${ }^{3}$

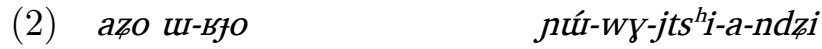

I 3SG:POSS-diluted.wine IPF-INV-CAUS:drink-1SG-DU

pul- $\iota t i$

PST.IPF-be.EMPH

They $_{d}$ gave me diluted wine to drink. (Kunbzang, 71)

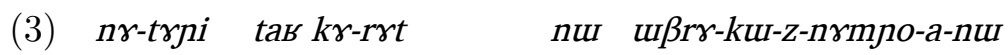

2SG-staff on NMLZ:O-write TOP QU-2 $\rightarrow 1$-CAUS-observe-1SG-PL

Could you show me what is written on your staff? (The prince, 61 )

\footnotetext{
${ }^{2}$ The causative verbs $s u-\beta z u$ 'cause to do' and $\gamma^{\gamma-k^{h} u}$ 'cause to be possible' can be used with verb complements to express causation; this construction is not discussed in the present paper.

${ }^{3} 3 \rightarrow 1$ SG and $2 \rightarrow 1$ SG forms are chosen because these are the only ones where the number and person of both arguments are indexed on the verb.
} 
(4) nr-pi ni ku nut

2SG.POSS-elder.sibling DU ERG DEM

Iŕ-wy-sut-tcat-a-ndzi $\quad$ cti

PFV-INV-CAUS-take.out-1SG-DU be.EMPH:FACT

Your two elder sisters forced me to spit it out. (The three sisters, 254)

Second, we find ambiguous causative forms for some verbs, where either the agent or the patient of the original verb is preserved: in other words, the $\mathrm{O}$ of the causative verb can either correspond to the original $\mathrm{A}$ of the original $\mathrm{O}$. These two types of derivation would respectively belong to types iv. and v. in Dixon (2000: 48)'s typology): shift of either the A or the O of the original verb to non-core status. Note that in Japhug the non-core status of these arguments is indicated by the absence of agreement on the verb, not by any overt marking on the noun phrases.

As an example, the causative of qur "to help" sur-qur has two meanings:

(5) tr-kut-sui-qur-a-ndzi

PFV-2 $\rightarrow$ 1-CAUS-help-1SG-DU

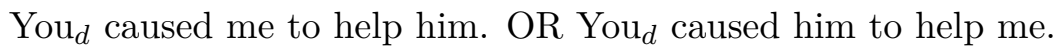

Similarly the causative of mto "to see" sum-mto means either "to cause X to be seen" or "to show to X (to cause X to see)":

(6) kum pu-a-pa sti ri, kum Ir-tur-cul-t door PST.IPF-PASS-close be.EMPH:FACT but door PFV-2-open-PST tce, turme ra ku pu-ku-su-mto-a LNK people PL ERG PFV-2 $\rightarrow 1$-CAUS-see-1SG

The door was closed, but you opened it, you caused me to be seen by the people. (elicited, Chen Zhen 2011)

(7) kuki laxtch ${ }^{h}$ ki wuma zo nu-car-a ri, ąo this thing this very EMPH PFV-search-1SG but I mu-pu-mto-t-a ri, nъъo kui pu-ku-sui-mto-a NEG-PFV-CAUS-See-PST-1SG but you ERG PFV-2 $\rightarrow 1$-CAUS-see-1SG

I looked for this thing for a long time, but could not find it, but you showed it to me. (elicited, Chen Zhen 2011)

(8) kopla trjpa pju-ku-su-mto-j u-jry? real snow IPF-2 $\rightarrow$ 1-CAUS-see-1PL INTRG-be.possible:FACT

Can you show us real snow? (The snow08.25)

Here is an example of O-preservation from a narrative: 


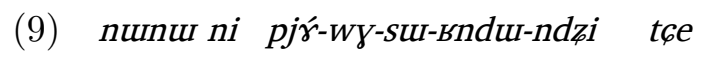

DEM DU IFR-INV-CAUS-beat-DU LNK

They $_{p}$ had the two of them beaten (by people). (not to be understood as: "They made two people beat them", Fox 126)

Preservation of the original $\mathrm{O}$ instead of the $\mathrm{A}$ occurs in verbs with human patients, when the patient is higher than the agent on the empathy hierarchy (in example 6, first person > third person indefinite), or, when all arguments are third person, when the $\mathrm{O}$ of the original verb is more topical than the A (example 9).

Third, the causative appears in sentences with an overt instrument in the ergative case (example 10). This specific use of the su- prefix will be referred to as 'instrumental causative'.

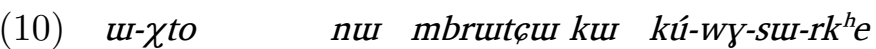
3SG.POSS-slit TOP knife ERG IPF-INV-CAUS-carve

The slit is carved with a knife. (Colored belts 13)

At least some irregular causatives are also used in this way:

(11) $\quad k^{h}$ rlr $\beta$ ku $\quad$ tut ${ }^{h} u$ рu-

cover ERG pan PFV-CAUS-cover-1SG

I covered the pan with a cover.

The instrumental causative prefix su-can be added to a causative verb, resulting in two su-prefixes in the same form, as in 12 . This is the only case of recursive application of a prefix in Japhug.

nunu ku pjú-wy-sur-sur-spos gut-pu

DEM ERG IPFV-INV-CAUS-CAUS-have.a.hole SENS-be

One makes a hole (into it) with this. (Plough, 8)

In the sentences above, using the verbs kú-wy-rkhe and pu-fkaß-a without the causative with the overt instrument is not ungrammatical; the instrumental causative is optional when the base verb is transitive. However, it is obligatory when the base verb is intransitive; using the non-causative form lo- $\beta z i$ IFR-become.drunk in example 13 would result in an ungrammatical sentence.

(13) $\quad c^{h a} \quad k u$ ló-wy-su- $\beta z i$

alcohol ERG IFR-INV-CAUS-become.drunk

He became drunk from the Chang. (elicited)

Animates can occur as instruments in some rare cases: 
(14) Bzar nunu ku, nunu, руа ku-xtci пш ra вға қо buzzard DEM ERG DEM bird NMLZ:S-small TOP PL entire EMPH tu-ndze вfa zо nunu ku u-xtu IPF-eat[III] entire EMPH DEM ERG 3SG.POSS-belly

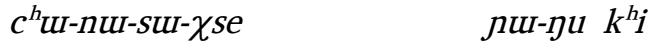
IPF-AUTOBEN-CAUS-feed[III] IPF-be HEARSAY

The buzzard always eats small birds, and always nourishes himself with them, it is said. (The buzzard, 3)

Although both instruments and A's are marked with the ergative, they differs from each other by their relativization patterns: instruments are relativized with the oblique participle $s \boldsymbol{r}$-instead of the S/A participle $k u-$ (see 15).
$\left[n u-m t^{h} \gamma\right.$
$s \gamma-x t c \gamma r]$
xсrfsa ma

3PL.POSS-waist NMLZ:OBLIQUE-tie thread apart.from

pjr-me

EVD.IPFV-not.exist

They only had threads to tie their waists (the only things that they could use to tie their waists were threads). (Milaraspa translation)

Fourth, the causative also occurs in very special syntactic constructions involving stative verbs. First, the causative form of a stative verb can occur with the infinitive of an action verb as its complement, expressing the manner of the action:

\section{(16) $\quad k \gamma-$-yndzur $c^{h} \gamma$-sut-rmprm}

INF-grind IFR-CAUS-homogeneous

He ground it smooth.

In this construction, we observe raising of the directional prefix of the complement verb (in the example above, for instance, the intrinsic directional prefix of yndzur "to grind" is $t^{h} u-/ c^{h} \gamma$ - "downstream"). Both the causative verb and the complement transitive verb share the same A and O.

Second, the causativized stative verb occurs as the first element of a serial verb construction, expressing again the manner or circumstances of the second verb:

$$
\begin{aligned}
& \text { (17) a-ts }{ }^{h} a \quad \text { ci pu-z-mrke pu-rke } \\
& \text { 1SG.POSS-tea a.little IMP-CAUS-be.before[III] IMP-put.in[III] } \\
& \text { Serve me some tea first. }
\end{aligned}
$$

As in all such constructions, both verbs share the verb TAM and person features.

The causee (the original A) can be marked with the ergative, as seen in the examples above. When the causee is an instrument, ergative marking is 
obligatory, and one can find sentences with two ergatives, though these are rarely attested in stories:

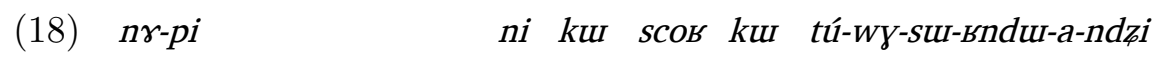

2DU.POss-elder.sibling DU ERG ladle ERG IPF-INV-CAUS-hit-1SG-DU

pul-cti ţe, nъъо kúnr nu tr-ste

PST.IPF-be.EMPH LNK you also DEM IMP-do.this.way[III]

jry

be.possible:FACT

Your two sisters hit me with a ladle, you can do the same. (Sentence retold by Chen Zhen from the story "The three sisters")

However, we do find causees without ergative. First, topicalized ones (with a pause after the topicalizer):
$p^{h}$ uni
nu, $\operatorname{tssaq}^{h} u$
rngui tas
broom.shrub TOP side.of.the.road rock on
a-z-I $\gamma$-su-rpe
ra
IRR-TRANSL-PFV:upstream-CAUS-bump.into[III] have.to:FACT

With the broom shrub, you will have to touch the rock on the road. (Smanmi2.62)

Second, when the causee is human, the ergative rarely appears (though it is not ungrammatical):

(20) t6 ${ }^{h}$ eme nut kujpu ku-wxtu-wxti zo

girl TOP oath NMLZ:STAT-INTENS-big EMPH

pa-sul-ta-ndzi

PFV:3 $\rightarrow 3$ '-CAUS-put-DU

They forced the girl to take a great oath. (Fox, 141)

When the original verb is intransitive, the causee is not marked with ergative (this does not apply to cases of instrumental causative).
tr-se
$m t s^{h} u$ tú-wy-sul-mts ${ }^{h} \gamma t$

INDEF.POSS-blood lake IPF-INV-CAUS-full

Let's fill the lake with blood. (Smanmi2.95)

The stative verb $m t^{h_{\gamma} t}$ "be full" can appear with both the container and the containee without case marking (the container is the real $\mathrm{S}$, while the containee is an adjunct). Adding causative marking on the verb does not promote the containee to core argument status.

\subsubsection{Compatibilities}

The causative -su- is highly productive and can appear with various other derivational prefixes, including the reflexive $-\not \gamma^{\gamma}$-, the causative $\gamma^{\gamma}$, the 
passive $a$-, the autobenefactive-spontaneous -nu- and all other derivational prefixes.

The reflexive $-z y \gamma$ - is the only derivational prefix that occurs before the causative. Only the order - $\boldsymbol{z} \boldsymbol{\gamma} \boldsymbol{\gamma}$-su- is attested, and the reverse order is unintelligible to Japhug speakers.

The combination of these two prefixes could potentially have two interpretations: either $\mathrm{X}$ cause $\mathrm{Y}$ to do to $\mathrm{X}$ (scope of the reflexive over the causative), or $\mathrm{X}$ cause to $\mathrm{Y}$ to do to $\mathrm{Y}$ (scope of the causative over the reflexive). However, only the first interpretation is possible, as shown by the examples:

(22) put-zyr-su-sat

PFV-REFL-CAUS-kill

$\mathrm{He}_{i}$ caused (him, them) to kill himself

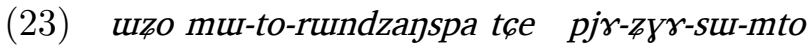

he NEG-IFR-careful LNK IFR-REFL-CAUS-see

He wasn't careful enough and got himself seen.

The two sentences above cannot be understood as " $\mathrm{He}_{i}$ caused (him, them $)_{j}$ to kill (him,them)selve(s) ${ }_{j}$ " or "he $i$ caused him hi $_{j}$ to see himself ${ }_{j}$ ".

The causative commonly appears with the autobenefactive-spontaneous nur:

uU-SCi iGqha $\quad$ uI-Srob nuI

3SG.POSS-replacement the.aforementioned 3SG.POSS-life TOP

$u-k \gamma-k u-r i \quad$ nunu

3SG-PFV-NMLZ:A-save DEM

z-la-nut-sur-ge-nut

TRANSL-PFV: $3 \rightarrow 3$-AUTOBEN-CAUS-COMe-PL

In his $j$ place, they (send people) to invite $\operatorname{him}_{i}$ to come, he ${ }_{i}$ who saved her life. (the demon, 162)

The causative also appears in combination with the passive as $\boldsymbol{s} \boldsymbol{r}<$ suI- $\boldsymbol{\gamma}$-, but only in a limited number of verbs:

$\boldsymbol{s} \boldsymbol{s} \boldsymbol{m b i}$ "to require something from someone" is a causative form derived from the passive $a-m b i$ "to be given" of the verb $m b i$ "to give". Etymologically, the verb means "to cause someone to give to oneself".

$\boldsymbol{s r j t s}^{\boldsymbol{h} \boldsymbol{i}}$ "to ask for something to drink" derives from the irregular lexicalized causative $j t s{ }^{h_{i}}$ "to give to drink". The etymological causative prefixes $j$ being fossilized and not analysed synchronically as such in modern Japhug, this form is not a counterexample to the verbal template. As mbi "to give", $j t s^{h} i$ has the recipient coded as the $\mathrm{O}$ : 
$(25)$

a-wU $\quad$ tur-ci

1SG.POSS-grandfather INDEF.POSS-water

лuu-ku-jts ${ }^{h-t c i} \quad$ ú

IPF-2 $\rightarrow$ 1-give.to.drink-1DU QU-could:FACT

Grandfather, could you give us water to drink? (Nima Vodzer 72)

$\boldsymbol{s} \boldsymbol{\gamma} \boldsymbol{\beta} \boldsymbol{z u}$ "to prepare, to make ready to use" derives from $\boldsymbol{a}-\beta z u$, a verb whose meaning in modern Japhug is "to grow", but which originally was the passive of $\beta z u$ "to make". sr $\beta z u$ is therefore etymologically "to cause to be made". The reflexive prefix $z \gamma^{\gamma}$ - can further be added to form the verb

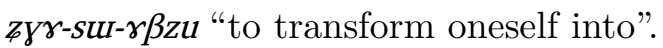

srpa "transform (tr.)" is the causative of apa "become", itself the passive of the verb pa, which means "close (the door)" in modern Japhug (among other meaning) but used to be the regularly verb "to do" in Rgyalrongic languages. srpa is always transitive.

This verb can in turn be combined with the reflexive $z \gamma \gamma$ to form

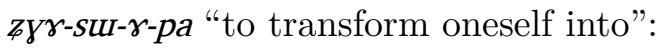
ü-tGuI
nui दkrru na-sul-rpa,
шъо xtut

3SG.POSS-son TOP serow PFV.3 $\rightarrow 3$-CAUS-become she wild.cat

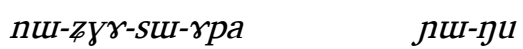

PFV-REFL-CAUS-become IPF-be

She changed her son into a serow, and herself into a wild cat. (Lobzang 54)

It is quite clear that the combination of the causative with the passive is not productive in Japhug, and that the analysis proposed above is only true from a diachronic perspective.

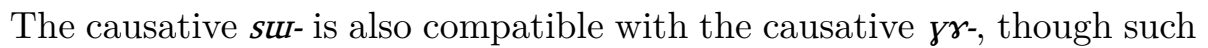
examples are unusual, and appear limited to the use of the causative to mark the instrument, as in 27.

(27) smrnba ku smrn no-k ${ }^{h} O$ tce, u-ku-mワrm doctor ERG medicine IFR-give LNK 3SG-NMLZ:STAT-hurt

to-z-yr-mna

IFR-CAUS-CAUS-be.cured

The doctor gave him a medicine and cured him with it.

\subsubsection{The semantics of the causative}

In his cross-linguistic overview of causatives, Dixon (2000: 62-68) proposes nine parameters to study the semantic specificities of causative constructions. The first two, state vs. action and transitivity, are treated in the morphology, and will not concern us here. 
Of the seven remaining parameters, three (Control, Volition, Affectedness) relate to the causee, and four (Directness, Intention, Naturalness, Involvement) to the causer; in this section, we will regroup them into four groups by combining directness, naturalness and involvement, as these three parameters are most often intertwined in our examples.

We will show that the su- causative in Japhug has a wide range of uses, and can appear independently of these parameters. Is it compatible with either obligation, authorisation, accompaniment or various modes of causation.

Control. The prefix sur- occurs both with actions on which the causee has control, but also with action on which he/it has no control, either because it is inanimate, or because the action itself is not controllable:

(28) uryrnpanma ku tur pjr-lrt, tcendrre nu-wa

Padmasambhava ERG poison IFR-use LNK 3PL.POSS-father

ko-z-nrndza,

IFR-CAUS-have.leprosy

Padmasambhava used a poison, and caused their father to contract leprosy. (Gesar 15)

Volition. The causative su- appears regardless of whether causee acts willingly ('let, ask') or unwillingly ('make, force').

This first example shows that the causative can be used when doing someone a favour:

(29) a-mu ndzu cin $ъ 0$

1SG.POSS-mother chopsticks even EMPH

a-mr-nut-tul-sul-qlut-nut

IRR-NEG-PFV-2-CAUS-break-PL

Please make sure that my mother does not even need to break chopsticks (go out to break twigs from the trees to make chopsticks; this idiomatic expression means "take care of her every need"). (Slobdpon, 220)

It can also be used when one asks someone to do something:

(30) Blama ku-wxti zо jr-sqrr-nu t6e, tr-rpi

lama NMLZ:STAT EMPH IFR-ask.to.do-PL LNK INDEF.POSS-sutra

ku-wxtur-wxti zo $\quad$ pr-su- $\beta z u-n u$

NMLZ:STAT-INTENS-big EMPH IFR-CAUS-do-PL

They employed a great lama and asked him to recite a major sutra.

(Rkang-rgyal, 19-20)

Finally, it can also express coercion, with adverbs such as trrkoz or mrkufts ${ }_{i}$ "forcefully": 
(31) $k \gamma$-ndza a-вjiz múij-yi ri шъо ku trrkoz NMLZ:O-eat 1SG-will NEG:SENS-come but he ERG forcefully $t^{h}$ úr-wy-sur-ndza-a PFV-INV-CAUS-eat-1SG

I did not want to eat it, but he forced me to. (Chen Zhen, 2005)

Intention. The causative prefix can appear with unintentional actions:
tur-nga jr-sul-rrgi-t-a
INDEF.POSS-clothes IFR-CAUS-blue-PST-1SG

I caused the clothes to become blue (unintentionally, by washing them the wrong way; el., Chen Zhen)

Directness, naturalness and involvement. The causative prefix sucan express various degrees of involvement on the part of the causer, as exemplified by the following example:

(33) uu-mbro ku qapri tuा-rdos пu pjr-z-rrtcas tсе, 3SG.POSS-horse ERG snake one-piece PL IFR-CAUS-trample LNK trte ku-wyrum nu lo-su-qios that.is NMLZ:STAT-white TOP IFRCAUS-vomit (Nyima Wodzer) had his horse trample one of the snakes, and caused it to throw up the white one (snake). (Nyima Wodzer,30)

In the first clause, the causee of the verb verb pjr-z-rrtcas "he caused him to trample" is the horse, while in the second one, the causee is the snake that was trampled; the causer (the character Nyima Wodzer) in the second case only acts indirectly (through the action of his horse).

The causative is also used to express authorisation, where the causer's involvement is even more indirect, and only amounts to an absence of action:

$$
\begin{aligned}
& \text { ku-kul-z-r子zi-a-nu } \quad \text { nu-nts }{ }^{h_{i}} \\
& \text { IPF-2 } \rightarrow 1 \text {-CAUS-stay-1SG-PL IPF-have.better } \\
& \text { Could you let me stay? (The raven, 68) }
\end{aligned}
$$

Finally, it can even appear in situations where the "causer" merely omits to act upon a naturally occurring event:

(35) $\quad$ tr-mt $t^{h} u m \quad \quad$ Ir-z-yrdi-t-a

INDEF.POSS-meat IFR-CAUS-be.smelly-PST-1SG

I let the meat spoil.

Some examples of sur-/z- have a semantics which is more reminiscent of the tropative (Jacques 2013a): znrja "consider to be a shame", supa "regard as" and znrkrro "consider to be acceptable".

The intransitive verb nrja means "to be a shame, to be a pity". 
the.aforementioned thing IFR-ACAUs:break PFV-be.a.shame

That thing broke, what a shame!

The transitive $z$-nrja, rather than meaning "to cause to be a shame" as expected regularly, rather means “to regret, be reluctant” (Chinese 不舍得), in other words "to consider something to be a pity":

(37) wuma zо pu-znrja-t-a

very EMPH PFV-regret-PST-1SG

I regretted it very much. (a lost cellphone cover, Dpalcan, conversation, 2010)

Another verb having unpredictable semantics with the prefix sur- is the transitive verb su-pa "to consider, to regard as". The original verb is pa "to close", etymologically "to do":

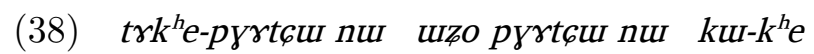

stupid-bird TOP he bird TOP NMLZ:STAT-stupid

tu-supa-nut

IPF-consider-PL

The r $^{h}$ e-pyrtcuu is considered to be a stupid bird. (the buzzard, 13)

\subsubsection{Scope ambiguity}

The causative presents scope ambiguity with several other prefixes, in particular negation and associated motion.

The negative prefix can either have scope over the base verb (cause not to do $=$ hinder) or over the causative (not cause to do). This may be an effect of the rigid verbal template, as the relative order of the negation and the causative are strictly fixed.

Examples with negation in the sense of "hinder", "cause not to do") are quite common:

(39) a-zuß $\beta$ múij-su-уe-пu

1SG-sleep NEG:SENS-CAUS-come-PL

They don't let me sleep. NOT "They do not cause me to sleep" (Dpalcan, 2010, elicitation)

(40) ut-tu-yrcraplan ku kopla

3SG-NMLZ:DEGR-make.noise ERG really

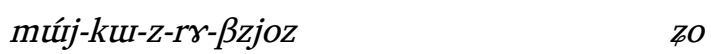

NEG:SENS-GENR:S/O-CAUS-APASS-learn EMPH

They make so much noise that they do not let people study at all. (Dpalcan, 2010, elicitation) 
$(41)$

nutcu ku-je the tur-ci

there IPF-keep.in.enclosure[III] LNK INDEF.POSS-water

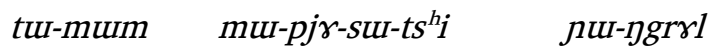

one-swallow NEG-IFR-CAUS-drink IPF-be.usually.the.case

(The male deer) prevent (the female) to leave the place, and do not let them drink even a swallow of water. (dictionary entry on "deer", 2005)

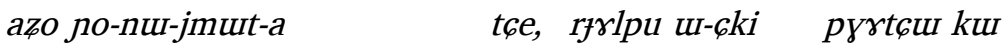

I IFR-AUTOBEN-forget-1SG LNK king 3SG-DAT bird ERG

mut-tr-sur-tut-a

NEG-PFV-CAUS-say[II]-1SG

I forgot it, so on my account the bird did not convey its message to the king (literally: I did not let the bird tell the king) ${ }^{4}$

However, the alternative interpretation, with the scope of the negation on the causation is also possible:

(43) ąo 6-tr-nu-tut-a

ma turme

I TRANSL-PFV-AUTOBEN-say[II]-1SG apart.from people

mut-tr-sur-tut-a

NEG-PFV-CAUS-1SG

I went to convey (the message) myself, and I did not make anyone else convey it.

A scope ambiguity is also observed with the associated motion prefixes cur- 'go and' and $\gamma u-$ - 'come and' (on which see Jacques 2013b). In Japhug, associated motion prefixes normally have accusative alignment: the referent undergoing the motion is either the $\mathrm{A}$ or the $\mathrm{S}$ of the verb (depending on its transitivity), never the $\mathrm{O}$. However, in the case of verbs with a causative sul-, the referent in motion can be either the the causer (as in 44, where the causative is used to indicated the presence of an instrument), the causee (as in 45 ) or both.

(44) wort $^{h}{ }^{h}$ қо, kuki jr-tsum tce, $t^{h}$ uci ftcaka kura tsuku please EMPH this IMP-take.away LNK something thing these some 6 -tr-sut- $\chi$ ti TRANSLOC-IMP-CAUS-buy[III]

Please, take this and go to buy something with it. (The raven4 72)

\footnotetext{
${ }^{4}$ This example is adapted from a traditional story; the speaker here is the shepherd Askyabs kulry acr $\beta$, whom a bird (in fact a reincarnated queen) asks to deliver a message to the king. The bird itself does not go to see the king directly.
} 
(45) tce kupa $c^{h} u$ nura $a t^{h_{i}} \quad$ p 6 os nura,

LNK Chinese LOC DEM:PL downstream direction DEM:PL

ü-pqi nura ku kureri

3SG-outside DEM:PL ERG here

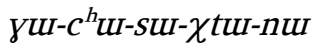

$\eta u$.

CISLOC-IPFV:DOWNSTREAM-CAUS-buy-PL be:FACT

People from the Chinese areas, people from outside send people to come here to buy (matsutake and sell them in the areas downstream). (hist-20grWBgrWB 58)

\subsubsection{The causative sur- with stative verbs}

Although the prefix $\gamma^{\gamma}$-, rather than su-, is used with most stative verbs, some stative verbs only appear with sur- The following non-exhaustive list illustrates some examples:

Table 5: Examples of the sur causative with stative verbs

\begin{tabular}{|c|c|c|}
\hline base & & causative \\
\hline arpi & blue & suI-rrฤi \\
\hline wyrum & white & sut-wyrum \\
\hline лав & black & suуу-лав \\
\hline yurni & red & z-yurni \\
\hline mrrtsa $\beta$ & spicy & $z$-mrrtsa $\beta$ \\
\hline$m \eta r m$ & be painful & Gu-mワrm \\
\hline
\end{tabular}

Stative verbs with a prefixal element ( $m \gamma^{-}, r \gamma^{-}, \gamma u-$ etc), always appear with $z$-, never with $\gamma \gamma$ - (except some examples with the prefixal element $a-$ ). This constraint explains for instance why the causative of mrrtsa $\beta$ "spicy" is in $z$ - rather than $\gamma^{\gamma}$-, while almost all other stative verbs denoting feelings or taste have a causative in $\gamma^{\gamma}$-, for instance tcur "sour" $>\gamma^{\gamma}$-t6ur "make sour", tsri "salty" $>\gamma^{\gamma}$-tsri "make salty" etc.

Color stative verbs and stative verbs related to disease and pain (ngo "sick", mørm etc) also do form their causative with sur- and its variants rather than with $\gamma^{\gamma}$-, as seen in the table above.

Very few stative verbs have been found which are compatible with both $\gamma^{\gamma}$ - and sur-; the semantic contrast between the two prefixes is treated in 2.2.3.

\subsection{The causative prefix $y^{\gamma-}$}

The causative $\gamma^{\gamma}$ - has a much more restricted usage than su- treated in the previous section. The prefix $\boldsymbol{\gamma}^{\boldsymbol{\gamma}}$-appears with most stative verbs, though 
as we have seen in 2.1.6, some stative verbs also appear with su-; the semantic differences between the two prefixes for stative verbs is treated in 2.2.3. Cognates of this prefix are found in other Rgyalrongic languages (in Tshobdun and in Khroskyabs, see Sun 2014 and Lai 2013) and in Tangut (Jacques 2014b: 253-4).

Unlike $s u-, \gamma^{\gamma}$ - presents no allomorphy. With verbs having the intransitive determiner $a$-, this syllable is absorbed by the prefix. For instance, the causative of artum "round" is $\boldsymbol{\gamma} \boldsymbol{\gamma}$-rtum "to coil (threads)".

\subsubsection{Syntactic constructions}

Unlike su-, $\boldsymbol{\gamma} \boldsymbol{\gamma}$ - only appears with stative intransitive verbs. The added argument, the causer, is always the A, while the original $\mathrm{S}$ becomes the $\mathrm{O}$.

(46) uu-mke $c^{h} O-\gamma \gamma-r n j i$

3sG-neck IFR-CAUS-long

He stretched his nec.k (elicited, Dpalcan 2010)

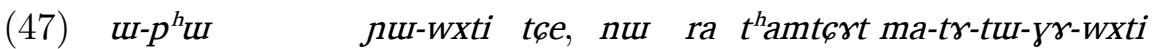

3SG.POSS-price SENS-big LNK DEM PL all NEG-IMP-2-CAUS-big

It is expensive, don't make it that expensive. (Bargaining, 11)

Like the prefix sur- (see 2.1.2), causative verbs with $\gamma^{\gamma}$-are used with a complement in $k$ - infinitive to express the manner in which the action takes place:

(48) pasndza $k \gamma-r \gamma k r u$ pa- $\gamma \gamma-n d u ß \beta$

pig.food INF-cut PFV:3 $\rightarrow 3$-CAUS-fine

He chopped the pig food very fine. (elicited, Dpalcan 2010)

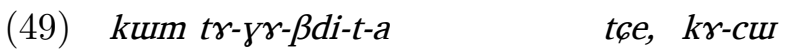

door IFR-CAUS-good-PST-1SG LNK INF-open

$t \gamma-y \gamma-k^{h} u-t-a$

IFR-CAUS-be.possible-PST-1SG

I repaired the door, so that it can be opened. (literally: I made the door openable, el. Chen Zhen, 2011)

As with the construction involving the prefix sur-, we observe that the directional prefix of the complement verb (in the infinitive) is raised to the causativized stative verb: pu- "down" and $t \boldsymbol{r}$ - "down" are respectively the intrinsic directional prefixes of rrkru "cut" and cu "open" (this verb also occurs with $k$ - "towards east").

In this construction, the scope of the negation is normally on the causativized stative verb, not on the whole action: 
(50) $k \gamma-r \gamma t \quad m u-p j \gamma-t u-\gamma \gamma-\beta d i-t$

INF-write NEG-IFR-2-CAUS-good-PST

You did not write it well ("you wrote it badly", not in the sense "you did not write it at all"), (el. Chen Zhen 2011)

(51) $k^{h}$ rdab tr-suffsay tce $t^{h} u$-mqlas ma $k \gamma$-sci Khatag IMP-fumigate LNK IMP-swallow otherwise INF-be.born mul-nu-tur- $\gamma^{\gamma}-k^{h} u-t$ NEG-PFV-CAUS-be.possible-PST

Fumigate a khatag and swallow it, otherwise you would make my birth impossible. (NOT: "you did not make my birth possible"). (Gesar, 61)

The raising of the directional prefix from the complement verb to the causativizer stative verb can remain even when the complement verb is elided. For instance, with a verb such as $\gamma^{\gamma}$-xtut "shorten", one can distinguish between:

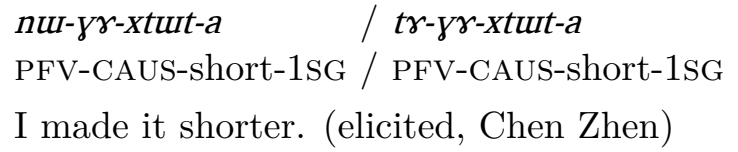

The first form means "shorten by cutting (clothes)", as the implicit complement verb is qru "cut", whose intrinsic directional prefix (in the meaning "to cut clothes") is nur-. nuI- $\gamma \gamma$-xtut-a is actually a short form for:
tur-pga
$k \gamma$-qrui nu- $\quad \gamma \gamma-x t u t-a$
INDEF.POSS-clothes INF-cut PFV-CAUS-short-1SG
I made the clothes shorter. (el., Chen Zhen)

tr-yr-xtut-a, with the prefix $t \boldsymbol{\gamma}$ "up" instead means that the clothes were made shorter by rolling sleeves up, without cutting the cloth.

\subsubsection{Compatibilities}

The prefix $\gamma^{\gamma}$-, is incompatible with other valency-increasing prefixes such as the tropative $n \boldsymbol{r}$ - and the applicative $n \boldsymbol{n} \boldsymbol{}$-. However, both the reflexive zor $r$ - and causative sul- can appear before it:

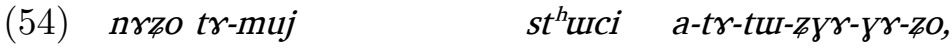

you INDEF.POSS-feather so.much IRR-PFV-2-REFL-CAUS-light,

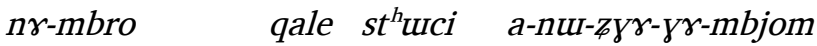

2SG.POSS-horse wind so.much IRR-PFV-REFL-CAUS-fast

May you be as light as a feather, and your horse as swift as the wind. (Smanmi Metog Koshana, 62) 
Example 27 above (2.1.3) illustrates a verb with both causative prefixes.

It also with the reciprocal a- + REDUPLICATION in forms such as rlab "to

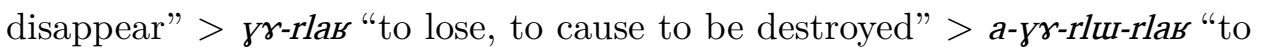
destroy each other". The reverse order is however not possible.

\subsubsection{Semantics}

Sun $(2006,2014)$, with regard to the causative prefixes $s \boldsymbol{r}$ - and $w \boldsymbol{E}$ - in Tshobdun, has shown that in the case of some stative verbs, the former indicates an increase of degree, while the latter expresses a change of state. This contrast appears to have been lost in Japhug (at least in the variety under study). Some labile verbs, such as mto (which means 'see' as a transitive verb and 'have the ability to see' as an intransitive stative verb') have distinct causative forms depending on the base meaning: sur-mto 'cause to see, show' is based on the transitive mto, while $\gamma \gamma$-mto 'cause (a blind person) to recover sight' is based on the stative mto.

\subsection{Abilitative}

The abilitative sur- is homophonous with the causative, and does present two allomorphs sur-and $z$ - with the same distribution as for the causative. ${ }^{5}$ The abilitative expresses that the $\mathrm{S} / \mathrm{A}$ is physically able to realize the action described by the verb. It is completely homophonous with the causative; for instance sur-ndza means both 'cause/force to eat' and 'be able to eat'. Although it appears to be quite productive (it can be applied to most transitive voluntary verbs), it is quite rare in the corpus, and most commonly appears in negative forms (see 55).

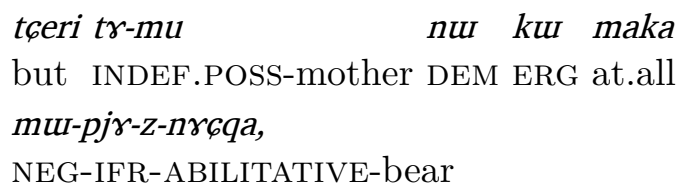

But the old woman was not able to resist (couldn't help) (and told them). (The three sisters 2014, 596)

The only case of irregular abilitative is the verb $s p^{h} u t$ 'be able to cut through (of a cutting instrument)' (see example 56) derived from $p^{h} u t t^{\prime}$ cut, pick, pluck', with the allomorph $s$ - and with more restricted semantics.

(56) tsuntu ku uu-ndzrui múuj-s-p $p^{h}$ ut ma scissors ERG 3SG.POSS-nail NEG:SENS-ABILITATIVE-cut because ut-tuu-rko ut-tu-jas 3SG-NMLZ:DEGREE-hard 3SG-NMLZ:DEGREE-thick

\footnotetext{
${ }^{5}$ Only examples with transitive verbs have been found; thus there are no allomorphs sur $\gamma^{-}$and $s \gamma-$, that can only be found on intransitive verbs.
} 


\section{jü-srre $\quad$ ¿o}

SENS-be.extremely EMPH

Scissors cannot cut through her nails, as they are very hard and thick. (notes 2012.8.6)

The transitive verb spa 'be able to (through learning)' is a lexicalized abilitative that has cognates outside of the Rgyalrong group, in particular in Tangut (Jacques 2014b: 255-6), showing that the abilitative must be reconstructed for a larger group of languages than simply Rgyalrong.

\subsection{Denominal derivation}

In addition to the causative and abilitative su-, denominal verbs in sul $/ z-/ s u r-/ s \gamma-$ can be either transitive or intransitive, and belong to four semantic categories: property, position, use of an instrument or body part, and causative, as presented in table 2.4 .

When a verb is derived from a possessed noun, the indefinite possessor prefixes $t \boldsymbol{r}-\mathbf{t} \boldsymbol{t} \boldsymbol{u}$ - or the other possessive prefixes are not preserved, and the prefix is directly added to the nominal root (Jacques 2014a). In Table 2.4, possessed nouns are indicated with the indefinite possessive prefix between brackets.

Table 6: Examples of denominal verbs in sur-and $s \boldsymbol{r}$ - in Japhug

\begin{tabular}{|c|c|c|c|c|c|}
\hline Category & Transitivity & Derived verb & Meaning & Base noun & Meaning \\
\hline \multirow[t]{2}{*}{ property } & intr. & $s \gamma-n d \gamma \gamma$ & to be poisonous & $(t \gamma)-n d \gamma \gamma$ & poison \\
\hline & intr. & $s \gamma-m b r u$ & to be angry & $(t r)-m b r u$ & anger \\
\hline position & intr. & su-ndzupe & to sit (in a special way) & ndzupe & way of sitting \\
\hline instrument & intr. & su-веjlu & be left-handed & sejlu & left hand \\
\hline instrument & tr. & $s \gamma-k^{h} u I$ & to smoke & $(t \gamma)-k^{h} u I$ & smoke \\
\hline instrument & $\operatorname{tr}$ & su-fsay & $\begin{array}{l}\text { to perform } \\
\text { ritual fumigation }\end{array}$ & fsay & fumigation \\
\hline instrument & tr. & sury-ts ${ }^{h} a b$ & to sieve & $t s^{h} a b$ & sieve \\
\hline instrument & tr. & sury-ts ${ }^{h} w i$ & to dye & $t s^{h} w i$ & colour, paint \\
\hline causative & $\operatorname{tr}$. & sul-ctsi & to cause to sweat & (tur)-ctsi & sweat \\
\hline causative & $\operatorname{tr}$. & $s \gamma-r m i$ & to give a name & $(t \gamma)-r m i$ & name \\
\hline
\end{tabular}

Table 2.4 shows that the instrumental denominal use of su- is fully productive, as it can be applied to Tibetan loanwords (respectively bsan 'fumigation', $t s^{h} a g$ 'sieve' and $t s^{h}$ os 'paint').

\section{Historical derivation}

On the basis of the data in the previous section, we show that two grammaticalization pathways can be proposed in Japhug. First, the causative 
sur- was derived from the instrumental / causative denominal sur-, following a more general path of grammaticalization well-attested in Rgyalrong languages. Second, the abilitative is grammaticalized from the causative.

\subsection{From Denominal to Causative}

Previous research (Jacques 2014a) has shown that several valency-changing prefixes in Japhug (and in all Rgyalrong languages) are historically derived from denominal prefixes through a two-stage process. First, the base verb is nominalized to a bare infinitive, a nominal form comprising the verb root prefixed either by an indefinite possessor prefix $t u-/ t \gamma$ - or by a possessive prefix coreferent with the $\mathrm{O}$ in the case of transitive verbs. This nominalization neutralizes the transitivity of the verb. Then a denominal verb is created from this bare infinitive with a transitivity value different from the base verb.

Three voice prefixes in Japhug have been shown to originate from such a grammaticalization process: the antipassive $\boldsymbol{r} \boldsymbol{\gamma}$-, the deexperiencer $\boldsymbol{s} \boldsymbol{\gamma}$ - (on this prefix, see Jacques 2012c) and the applicative nut-, respectively from the intransitive denominal $r u-/ r \gamma-$, the (stative verb) property denominal $s \gamma$ - (seen above) and the transitive denominal nur-.

This grammaticalization pathway, which is not restricted to Rgyalrong languages but also attested in language families such as Mande (Creissels 2012) and Eskaleut (Fortescue 1996), can be summarized as follows:

(57) ACTION NOMINALIZATION of transitive verb + INTRANSITIVE DENOMINAL DERIVATION $\Rightarrow$ ANTIPASSIVE

(58) ACTION NOMINALIZATION of intransitive verb + TRANSITIVE DENOMINAL DERIVATION $\Rightarrow$ APPLICATIVE / CAUSATIVE

The same mechanism can explain the causative as being derived from the denominal sur-, which changes a noun $\mathrm{X}$ into a transitive verb meaning either 'use X' (instrumental denominal) or 'cause (people) to have X' (causative denominal). In addition to the phonological and semantic similarity between the causative and instrumental/causative denominal prefixes, we should note the fact that both share the same allomorphy su- $/ z-/$ sur $^{-}$, the same double meaning (instrumental and causative proper) which makes it extremely unlikely that both prefixes could be unrelated.

The opposite direction of derivation (from causative to denominal) is highly unlikely for two reasons.

First, in the case of the antipassive $r \gamma$-, there is strong evidence of the directionality of derivation from denominal to antipassive, as we find several examples of verbs whose nominal form and antipassive form share a common semantic or morphological innovation (Jacques 2014a). For instance, руав 'turn over, plough' has an antipassive $r \gamma$-руав meaning specifically 'reclaim 
land (plough for the first time)', with the same irregular restricted meaning as the derived noun tu-руав 'land reclamation'. While such examples have not been found in the case of the causative, the parallelism with other voice markers suggest that this direction of derivation is indeed the most likely. The denominal to causative derivation is almost a synchronic process and does not involve any reconstruction (all intermediate steps of the grammaticalization pathways are independently attested).

Second, while the extension of a causative marker to instrumental denominal function could be conceivable in an omnipredicative language where nouns are predicative in their own right, this seems impossible in a language with a very strong noun / verb distinction like Japhug, ${ }^{6}$ unless one explains the development of the denominal as a backformation from the causative following the pathways in 57 in the opposite direction.

Thus, of the three logically possible historical relationships between the causative and denominal su- (unrelated, causative to denominal, denominal to causative), only the last one is a likely explanation.

\subsection{From Causative to Abilitative}

Two distinct hypotheses can be put forward to explain the origin of the abilitative $s u-$ - directly from the denominal su- or indirectly from the causative su- after its creation from the denominal.

Although formally possible, the hypothesis that the abilitative derives from the denominal su- is not possible on semantic grounds: there are no denominal verbs derived from a noun $\mathrm{X}$ whose meaning is 'be able to do X'.

The derivation from the causative is also difficult at first glance, as abilitative and causative share little semantic commonality. Yet, there are cases where both an interpretation in terms of causative and one in terms of abilitative is possible and would have a very similar meaning, differing only in perspective. Example 59 is an example of abilitative with the verb su-rqoв 'be able to hug'.

$$
\begin{aligned}
& \text { turme lasnulaxsum kunn mr-kr-su-rqos } \\
& \text { people two.or.three also NEG-INF-ABILITATIVE-hug } \\
& \text { ku-fse ku-jpum } \quad \text { nu- } \beta z e \quad c^{h} a \\
& \text { INF:STAT-be.like NMLZ:S-be.thick IPFV-do[III] can:FACT }
\end{aligned}
$$

(The Fir) can grow so thick that two or three people cannot hug (its trunk). (Fir, 6)

However, it is also possible to construe the meaning in a different way: 'The fir can grow so thick that it prevents even two or three people from hugging (its trunk)', with a causative interpretation. This interpretation is

\footnotetext{
${ }^{6}$ Verb and nouns have very different morphological properties in Japhug, and there is no zero derivation from noun to verb.
} 
possible due to the ambiguity of the scope of the negation of the causative, which generates the preventive meaning 'prevent, hinder' in negative form, from which a modal meaning 'not able to' can be derived, if the causee, rather than the causer, is reanalyzed as the real A of the su- prefixed verb. This kind of reanalysis is particularly easy in Japhug as all of the arguments, whether S, A, O, causer or causee can be elided.

Examples such as 59 therefore constitute the pivot construction whose reanalysis has allowed the abilitative to be created out of the causative. This hypothesis accounts for the fact that nearly all examples of abilitative in natural speech are found in negative verb forms. We can propose the previously unknown pathway of grammaticalization:

(60) Negative + CAUsative $\Rightarrow$ PREVEntive $\Rightarrow$ NEgative + ABILITATIVE

not cause to $\mathrm{X} \Rightarrow$ prevent from $\mathrm{X} \Rightarrow$ be unable to $\mathrm{X}$ (by removing the causer and promoting the causee to A status)

The grammaticalization of the abilitative, as seen above, must predate he common ancestor of Rgyalrong and Tangut, but it is unclear whether the languages which have no trace of the abilitative have lost all traces of it or never have grammaticalized it.

\section{Comparative evidence}

While from a Japhug-internal point of view the derivation from denominal su- to causative seems straightforward, this hypothesis raises an important problem: the sibilant causative is one of the very few morphological element that appears to be ubiquitous in the Sino-Tibetan family. Indeed, even highly innovative languages such as Chinese and Lolo-Burmese appear to present traces of this prefix. In languages other than Rgyalrongic, the semantic of the causative cannot be studied in comparable detail as it has become completely lexicalized and is not any more the productive mechanism to express causation. In particular, the instrumental use of the causative attested in Japhug does not appear widespread outside of Rgyalrongic.

In this section, we present data from Tibetan and Chinese showing that data from these languages do not contradict the above hypothesis.

\subsection{Tibetan}

Of all ancient Sino-Tibetan languages, Tibetan is the only one which directly preserves the causative in a form that does not require a reconstruction. ${ }^{7}$ There is clear evidence of both the causative and the denominal $s$ - prefixes. $^{8}$ Examples of the causative are plentiful. Zhang (2009: 210-8) counts 107

\footnotetext{
${ }^{7}$ Tibetan in this paper is transcribed according to Jacques (2012a)'s conventions.

${ }^{8}$ The causative has an allomorph $z$ - before 1 -
} 


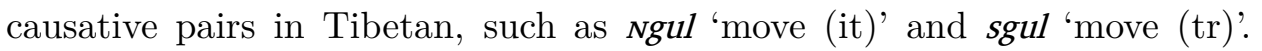
Although some of the pairs collected by Zhang Jichuan must be explained differently (in particular the ones that involve $s-/ z$-alternations such as $s u b$ 'rub off', zub 'be rubbed off'), there are about a hundred of good examples of causatives in $s$-in Tibetan.

Clear examples of the denominal $s$-are rarer and are generally less transparent semantically (for instance nag 'word' $\Rightarrow$ bspags 'extoll'), suggesting that productivity was lost before that of the causative. ${ }^{9}$

Yet, there is evidence also in Tibetan that the causative derives from the denominal. In almost all of these pairs, the intransitive counterpart has a prenasalized prefix $N$ - which is not usually commented on by comparativists. There is a frequent $N$ - present tense prefix appearing in intransitive verbs in Tibetan, but in the causative pairs, the $N$ - in the intransitive forms is in most cases not a tense marker: it is retained through the whole paradigm, and appears in both present and past stems.

In some cases, we find a cognate noun that does not have the $N$ - prefixal element, as in grib.ma 'shade, shadow' and grib 'defilement, stain' versus sgrib 'diminish, fail, be obstructed, be obscured' and sgrib 'cover'. Rather than assuming, as is generally done, a direct derivation from intransitive Ngrib to the transitive controllable sgrib, it is better for both semantic and morphological reasons to suppose that both verbs derive from the base noun, whose original meaning was 'shadow' (hence the secondary evolution to 'defilement, stain'), by addition of the denominal intransitive $N$ - and denominal causative $s$ - prefixes:

(61) $\quad$ grib(-ma) 'shade, shadow' $\Rightarrow N$-grib 'fail, be obscured' grib(-ma) 'shade, shadow' $\Rightarrow s$-grib 'cover'

The intransitive Ngrib has retained all the meanings of the original noun, and developed some more meanings, while the transitive sgrib 'cover' has only retained the base meaning of the noun.

Though in most cases no corresponding noun is found, it is likely that other examples of 'causative $s$ ' ' should be in fact historically analyzed as denominal prefixes. This question is deferred to further research, which will require corpus study of Old Tibetan texts.

\subsection{Old Chinese}

Already in antiquity, Chinese languages were phonologically and morphologically much more innovative than modern languages such as Rgyalrong or Kiranti. The remnants of former morphological alternations directly at-

\footnotetext{
${ }^{9}$ We also find one example of a denominal stative property verb snan 'pleasant (speech), melodious' from nan 'hear'.
} 
tested in modern varieties of Chinese are few and ambiguous, and can only be accessed through reconstructions.

Not all authors agree about how to interpret and reconstruct the traces of morphological alternations found in Chinese. In particular, an important debate concerns verbs pairs presenting a voicing alternation correlated with transitivity in Middle Chinese as presented in Table 7.

Table 7: Examples of voicing alternation in Middle Chinese

\begin{tabular}{|c|c|c|c|}
\hline Intransitive & Meaning & Transitive & Meaning \\
\hline 現 $y e n^{3}$ & appear & 見 $k e n^{3}$ & see \\
\hline 敗 $b æ j^{3}$ & be defeated & 敗 $p æ j^{3}$ & defeat \\
\hline 别 bjet & be different, leave & 别 pjet & separate \\
\hline 折 $d z e t$ & break, bend (it) & 折 $t 6 e t$ & break, bend (tr) \\
\hline
\end{tabular}

Some scholars believe that this type of voicing alternation ${ }^{10}$ is a trace of the cognate of the causative ${ }^{*} s$ - prefix, and that the transitive verbs derive from the intransitive ones, the ${ }^{*} s$ - prefix having a devoicing effect on the initial consonant (Mei 2012 is a representative example of this line of thought).

However, it is clear that this view is a misconception. In all phonologically conservative languages where the causative is preserved as a distinct segment, we also find traces of a distinct and historically unrelated voice alternation: anticausative prenasalization. Table 8 shows some examples of verb pairs in Japhug (see Jacques 2012c, ? for more details on the semantics of this derivation and for more examples). The anticausative prenasalization changes transitive verbs to intransitive with voicing of the initial stop or affricates (there are no examples of this alternation with verbs having sonorant or fricative initials). The directionality (from transitive to intransitive) is proven by two pieces of evidence.

First, the Tibetan loanword $\chi$ trr 'spill' (Tibetan gtor), whose intransitive counterpart $\boldsymbol{B n d}_{\boldsymbol{1}} \boldsymbol{r}$ 'be spilled' has no equivalent in Tibetan. Moreover the phonotactics of the cluster fricative+prenasalized voiced stop is incompatible with the phonotactic structure of Tibetic languages. Hence, this verb can only have been created within Japhug from its transitive counterpart $\chi$ trr 'scatter' after this latter had been borrowed.

Second, there are transitive verbs with aspirated or unaspirated obstruents, but this contrast is neutralized in the corresponding anticausative verbs.

Similar pairs can be found in languages such as Tibetan (Jacques 2012b, Hill 2014), Tangut (Gong 1988, Jacques 2014b: 245-8) or Jinghpo (Dai

\footnotetext{
${ }^{10}$ In the case of velars, there was no non-palatalized $g$ in Middle Chinese, so that the alternation $\gamma / k$ is expected, and all specialists of Old Chinese reconstruction agree that Middle Chinese $\gamma^{-}$- originates from ${ }^{*} g$-, see Baxter (1992).
} 
Table 8: Examples of the anticausative alternation in Japhug

\begin{tabular}{|c|c|c|c|}
\hline $\begin{array}{l}\text { Base verb } \\
\text { transitive }\end{array}$ & Meaning & $\begin{array}{l}\text { Derived verb } \\
\text { intransitive }\end{array}$ & Meaning \\
\hline$\chi t r r$ & spill & bndrr & be spilled \\
\hline prrt & break & mbrrt & break, cut (it) \\
\hline tсуав & squeeze out & ndzуав & be squeezed out (spontaneously) \\
\hline руав & turn over & mьуав & roll about (it) \\
\hline$x t^{h}$ om & to put horizontally & ndom & to be horizontal \\
\hline$c^{h} \gamma \beta$ & to flatten, to crush & $\operatorname{nfr} \beta$ & to be crushed, flattened \\
\hline cuI & to open & пғші & to be opened \\
\hline
\end{tabular}

1990: 78), which preserve the causative prefix as a distinct segment ( $s$ - in

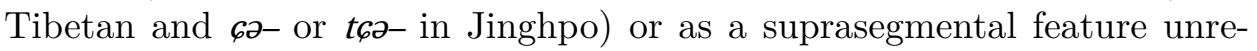
lated with voicing (Gong 1999, Jacques 2014b: 250-1). Since causative and anticausative derivations are clearly distinct in Tibetan, Rgyalrong, Tangut and Jinghpo, it is not possible that the verb pairs in Chinese such as those presented in Table 7 can be explained as being traces of a causative prefix ${ }^{*} s$ - (see also LaPolla 2003). ${ }^{11}$ It is more likely to assume, following Sagart \& Baxter (2012), that the voicing alternation in Chinese is cognate to the anticausative derivation.

While Sagart \& Baxter (2012) deny that verb pairs such as those in Table 7 are traces of the causative ${ }^{*} s$ - prefix, they still reconstruct a causative ${ }^{*} s$ to account for different alternations (Table 9).

Table 9: Examples of the causative ${ }^{*} s$ - in Old Chinese according to Sagart \& Baxter (2012)

\begin{tabular}{llll}
\hline & Middle Chinese & Old Chinese & Meaning \\
\hline 視 & $d_{z i j^{2}}$ & $\leftarrow{ }^{*}$ gij? & see \\
示 & $z i j^{3}$ & $\leftarrow{ }^{*} s-$ gijl-s & show \\
食 & $z i k$ & $\leftarrow{ }^{*}$ mə-lək & eat \\
飼 & $z i^{3}$ & $\leftarrow{ }^{*} s-m-l ə k-s$ & feed \\
\hline
\end{tabular}

It should be noted however that in nearly all the verb pairs provided by Sagart 1999 and Sagart \& Baxter (2012), the causative is actually indicated by a circumfix $* s-s$, with the verb prefixed and suffixed by $* s$. The reconstruction of a causative $* s$ - prefix is thus by no means straightforward.

\footnotetext{
${ }^{11}$ It is possible however, that in highly eroded languages like Lolo-Burmese, ancient *S+voiced obstruent clusters have become unvoiced, as specialists of these languages generally believe (??), so that distinguishing between anticausative and causative pairs is not straightforward on Lolo-Burmese internal grounds. Some verb pairs found in LoloBurmese (for instance Burmese prat vs phrat 'break') are also attested in Japhug (mbrrt 'break (it)' vs prrt 'break, cut (tr)'), showing that at least part of these voicing or aspiration alternations originate from anticausative prenasalization, not from causative ${ }^{*} s$.
} 
While all authors agree on the existence of examples, there are barely any example of a verb pair that is agreed on by all scholars.

By contrast, we do find examples of denominal ${ }^{*} s$ - that are accepted by all specialists, in the case of pairs between Middle Chinese 1 (from Old Chinese ${ }^{*} r-$ ) and $s^{-}$(from Old Chinese ${ }^{*} s r-$ ). Table 10 includes two of the most convincing pairs. Other pairs have been proposed, but their acceptance crucially depends on one's particular Old Chinese reconstruction system, and a detailed discussion goes beyond the scope of the present paper.

Table 10: Examples of the denominal ${ }^{*} s$ - in Old Chinese

\begin{tabular}{llll}
\hline & Middle Chinese & Old Chinese & Meaning \\
\hline 吏 & $l i^{3}$ & $\leftarrow{ }^{*}$ rə?-s & officer \\
使 & $s i^{2}$ & $\leftarrow{ }^{*} s$-rə? & send \\
率 & lwit & $\leftarrow{ }^{*}$ rut & norm, standard \\
率 & swit & $\leftarrow{ }^{*}$ s-rut & follow, go along \\
\hline
\end{tabular}

In conclusion, the only uncontroversial fact about Old Chinese morphology is the existence of a denominal ${ }^{*} s$ - prefix, whose exact semantics is unclear due to the dearth of examples. It is possible that a causative ${ }^{*}{ }_{s}$ prefix can be reconstructed, but the evidence is less clear and allows differing interpretations.

\section{Conclusion}

This paper provides the first detailed description of the two causative derivations in Japhug Rgyalrong, and in addition proposes two new pathways of grammaticalization.

First, it shows that the sur-causative in Japhug Rgyalrong is derived from the denominal instrumental / causative denominal derivation ( $\mathrm{X} \Rightarrow$ 'use X' or 'cause to have X') through a two-step process already attested for antipassive and applicative derivations (Jacques 2014a). Second, it suggests that the abilitative su- prefix evolved from the causative through reanalysis of the causee as the agent in negative forms, following pathway 62 .

$$
\text { NEGative }+ \text { CAUSATive } \Rightarrow \text { PREVEntive } \Rightarrow \text { NEGAtive }+ \text { ABILITATive }
$$

The first pathway has considerable implications for this family as a whole: both denominal and causative sibilant prefixes are found across the Sino-Tibetan family. The hypothesis proposed here implies either that only the denominal derivation is reconstructible to proto-Sino-Tibetan (and that the causative has been innovated independently several times from the denominal prefix throughout the family) or that the grammaticalization took place in proto-Sino-Tibetan times. 
We have shown that some apparent examples of causative $s$ - in Tibetan are better analyzed as denominal verbs, suggesting that the reanalysis from denominal to causative was still ongoing in Old Tibetan times. In the case of Chinese, the dearth of convincing examples of causative ${ }^{*} s$ - possibly implies that it has never developed a real causative prefix.

\section{References}

Baxter, William H. III. 1992. A Handbook of Old Chinese Phonology Trends in Linguistics, Studies and Monographs 64. Berlin: Mouton de Gruyter.

Benedict, Paul K. 1972. Sino-Tibetan: a conspectus. Cambridge: Cambridge University Press.

Conrady, August. 1896. Eine Indo-Chinesische causative-DenominativBildung und ihr Zusammenhang mit den Tonaccenten. Leipzig: Otto Harrassowitz.

Creissels, Denis. 2012. The origin of antipassive markers in West Mande languages. In 45th Annual Meeting of the Societas Linguistica Europaea, Stockholm.

Dai, Qingxia. 1990. 景颇语语法 Jingpōyǔ yǔfă (A grammar of Jinghpo). Běijing: Mînzú chūbǎnshè.

Dixon, R.M.W. 2000. A typology of causatives : form syntax and meaning. In R.M.W. Dixon \& Alexandra Y. Aikhenvald (eds.), Changing Valency, Case studies in transitivity, 30-30-83. Cambridge: Cambridge University Press.

Fortescue, Michael. 1996. West Greenlandic half-transitive affixes in a diachronic perspective. In Birgitte Jacobsen (ed.), Cultural and Social Research in Greenland 95/96, Essays in Honour of Robert Petersen, Nuuk : Ilisimatusarfik/Atuakkiorfik.

Gong, Hwang-cherng. 1988. Phonological Alternations in Tangut. Bulletin of the Institute of History and Philology 59.3. 783-834.

Gong, Hwang-cherng. 1999. 西夏語的緊元音及其起源 Xixiàyǔ de jinnyuányin jîîi láiyuán (Tense vowels in Tangut and their origin). Bulletin of the Institute of History and Philology 70.2. 531-558. (龔煌城).

Hill, Nathan W. 2014. A note on voicing alternation in the Tibetan verbal system. Transactions of the Philological Society 112.1. 1-4.

Jacques, Guillaume. 2008. 嘉䋐語研究 Jiāróngyǔ yánjiū. 北京：民族出版社 Běijīng: Mínzú chūbănshè. (向柏霖). 
Jacques, Guillaume. 2010. The origin of the reflexive prefix in Rgyalrong languages. Bulletin of the School of Oriental and African studies 73.2. 261-268.

Jacques, Guillaume. 2012a. A new transcription system for Old and Classical Tibetan. Linguistics of the Tibeto-Burman Area 35.2. 89-96.

Jacques, Guillaume. 2012b. An Internal Reconstruction of Tibetan Stem Alternations. Transactions of the Philological Society 110.2. 212-224.

Jacques, Guillaume. 2012c. Argument demotion in Japhug Rgyalrong. In Katharina Haude \& Gilles Authier (eds.), Ergativity, Valency and Voice, 199-226. Berlin: Mouton De Gruyter.

Jacques, Guillaume. 2012d. From denominal derivation to incorporation. Lingua 122.11. 1207-1231.

Jacques, Guillaume. 2013a. Applicative and tropative derivations in Japhug Rgyalrong. Linguistics of the Tibeto-Burman Area 36.2. 1-13.

Jacques, Guillaume. 2013b. Harmonization and disharmonization of affix ordering and basic word order. Linguistic Typology 17.2. 187-217.

Jacques, Guillaume. 2014a. Denominal affixes as sources of antipassive markers in Japhug Rgyalrong. Lingua 138. 1-22.

Jacques, Guillaume. 2014b. Esquisse de phonologie et de morphologie historique du tangoute. Leiden: Brill.

Lai, Yunfan. 2013. La morphologie affixale du lavrung wobzi. Université Paris III MA thesis.

Lai, Yunfan. 2014. Causative Constructions in Wobzi. In 14th International Symposium on Chinese Languages and Linguistics, .

LaPolla, Randy. 2003. An overview of Sino-Tibetan morphosyntax. In Graham Thurgood \& Randy J. LaPolla (eds.), The Sino-Tibetan Languages, 22-42. London \& New York: Routledge.

Matisoff, James A. 2003. Handbook of Proto-Tibeto-Burman, vol. 135 University of California Publications in Linguistics. Berkeley and Los Angeles: University of California press.

Mei, Tsulin. 2012. The causative ${ }^{*}$ s- and nominalizing $*_{-s}$ in Old Chinese and related matters in Proto-Sino-Tibetan. Language and Linguistics 13.1. $1-28$. 
Michailovsky, Boyd, Martine Mazaudon, Alexis Michaud, Séverine Guillaume, Alexandre François \& Evangelia Adamou. 2014. Documenting and researching endangered languages: the Pangloss Collection. Language Documentation and Conservation 8. 119-135.

Sagart, Laurent. 1999. The roots of Old Chinese. Amsterdam: Benjamins.

Sagart, Laurent \& William H. Baxter. 2012. Reconstructing the s- prefix in Old Chinese. Language and Linguistics 13.1. 29-59.

Sun, Jackson T.-S. 2006. 嘉戎語動詞的派生形態 Jiāróngyǔ dòngcî de pàishēng xîngtài (Derivational morphology in the Rgyalrong verb). Minzu yuwen 民族語文 4.3. 3-14.

Sun, Jackson T.-S. 2007. Morphological causative formation in Shangzhai Horpa. Bulletin of Chinese Linguistics 1.2. 207-227.

Sun, Jackson T.-S. 2014. Sino-Tibetan: Rgyalrong. In Rochelle Lieber \& Pavol Štekauer (eds.), The Oxford Handbook of Derivational Morphology, 630-650. Oxford: Oxford University Press.

Sūn, Hóngkāi. 1982. 獨龍語簡誌 Dúlóngyǔ jiănzhi (A Brief Description of Dulong). 北京：民族出版社 Běijīng: Mínzú chūbǎnshè.

Wolfenden, Stuart. 1929. Outlines of Tibeto-Burman linguistic morphology, with special reference to the prefixes, infixes and suffixes of classical Tibetan and the languages of the Kachin, Bodo, Năgă, Kuki-Chin and Burma groups. London: Royal Asiatic Society.

Zhang, Jichuan. 2009. 藏语词组研究 Zàngyǔ cîzú yánjiū (a study of word families in Tibetan). Beijing: Shehui kexue wenxian chubanshe. 